\title{
Pitfalls of Wastewater Treatment in Oil Refinery Enterprises in Kazakhstan-A System Approach
}

\author{
Ivan Radelyuk 1,2,3,*(D), Kamshat Tussupova ${ }^{1,2,4}$, Kulshat Zhapargazinova ${ }^{3} \mathbb{D}$, \\ Madeniyet Yelubay ${ }^{3}$ and Magnus Persson ${ }^{1}$ \\ 1 Department of Water Resources Engineering, Lund University, Box 118, SE-22100 Lund, Sweden; \\ kamshat.tussupova@tvrl.lth.se (K.T.); magnus.persson@tvrl.lth.se (M.P.) \\ 2 Center for Middle Eastern Studies, Lund University, SE-22100 Lund, Sweden \\ 3 Department of Chemistry and Chemical Technology, Pavlodar State University, Pavlodar 140000, \\ Kazakhstan; gul_0859@mail.ru (K.Z.); madik_chimik@mail.ru (M.Y.) \\ 4 Department of Public Health, Karaganda State Medical University, Karaganda 100004, Kazakhstan \\ * Correspondence: ivan.radelyuk@tvrl.lth.se; Tel.: +46-790-582-168
}

Received: 28 January 2019; Accepted: 12 March 2019; Published: 18 March 2019

\begin{abstract}
The present article is an assessment of wastewater treatment processes in the oil refinery sector in Kazakhstan by comparing relevant experience of developed and developing countries. The legislation in this sphere, the treatment methods, the discharge process and the effect on the environment were evaluated following international and national regulations. In our study, the wastewater systems in three factories in Kazakhstan were assessed. Results show that, even though the environmental regulation in Kazakhstan promotes the polluter pays principle and follows the World Health Organization (WHO) recommendations, the oil refinery plants in Kazakhstan still contain exceeding concentrations of pollutants in their effluents. One issue is that the local legislation allows disposal of wastewater to natural or artificial ponds as long as the concentrations of pollutants in effluents are less than the already existing concentrations in the pond. Consequently, the factories can use ponds with an initially high concentration of contaminants. The high initial concentration of pollutants in the pond water is due to wastewater discharged before the implementation of current environmental regulations. This issue in the current legislation leads to the situation where there is no incentive for efficient wastewater treatment. The national law also lacks regulations regarding which methodology should be used to assess the pollutants in the wastewater. Thus, the control by national environmental office for each enterprise is negotiated separately between the factory and the governmental body. This gives the factory a strong position to define the parameters assessing the effluents. This has led to none of the factories measuring, e.g., heavy metals in discharged wastewater. Total petroleum hydrocarbons (TPH) concentration in wastewater is often exceeded at each factory and there is no analysis done for different hydrocarbon fraction. To overcome the issues described in the present study, we strongly recommended a unified and transparent methodology for the country's oil refinery industry to assess important pollutants in discharged wastewater.
\end{abstract}

Keywords: industrial wastewater; groundwater; water pollution; oil refinery; legislation; Kazakhstan

\section{Introduction}

Modern Kazakhstan is a country with a constantly developing economy and industry is Kazakhstan's economical base, with stable growth during the last 20 years. The refining enterprises also significantly contribute to the structure of industrial development [1]. Kazakhstan is the second biggest oil producer after Russia among the Commonwealth of Independent States countries. The petroleum industry is the major actor and accounted for about 10\% of the country's GDP in 2016 [2]. Kazakhstan 
is one of the key suppliers of hydrocarbon raw materials for the world economy. In 2016, Kazakhstan was rated 16th in the world with a production volume of 79.3 million tons of oil and gas condensate (representing 2\% of the global production). The refinery throughput in Kazakhstan is 339 thousand barrels daily, a number that is growing by $4.6 \%$ every year. The refinery capacity is estimated to be 350 thousand barrels daily [3].

Water is a very important reagent in petroleum and petrochemical production processes. Distillation, extraction, preparation of solutions, cooling systems and washing processes are some examples of industrial water use [4], leading to a large consumption in the current fuel and electricity production. The total water consumption for those purposes is projected to increase by $55 \%$ between 2000 and 2055 globally [5].

The total water consumption in the Republic of Kazakhstan in 2016 was estimated to be $24.7 \mathrm{~km}^{3}$, including $5.23 \mathrm{~km}^{3}$ (representing about $20 \%$ ) for industrial needs. The largest share of the industrial water use is found in heat power engineering, non-ferrous metallurgy, and the oil industry [6].

Historically, the oil refinery industry has been associated with groundwater pollution. Effluents from factories contain numerous hazardous toxic pollutants, which have mutagenic properties, leading to carcinogenic disease through groundwater [7]. Contaminants may easily reach groundwater as a result of discharge to surface water bodies and subsequent infiltration down to the groundwater [8].

The current scheme of water cycle in Kazakhstan's industrial sector is presented in Figure 1. It is clearly seen that legislation regulates all water use processes. Despite this, the problem of environmental pollution exists due to refinery activities. This study aimed at investigating a situation in the sphere of water use by the oil refinery industry in Kazakhstan.

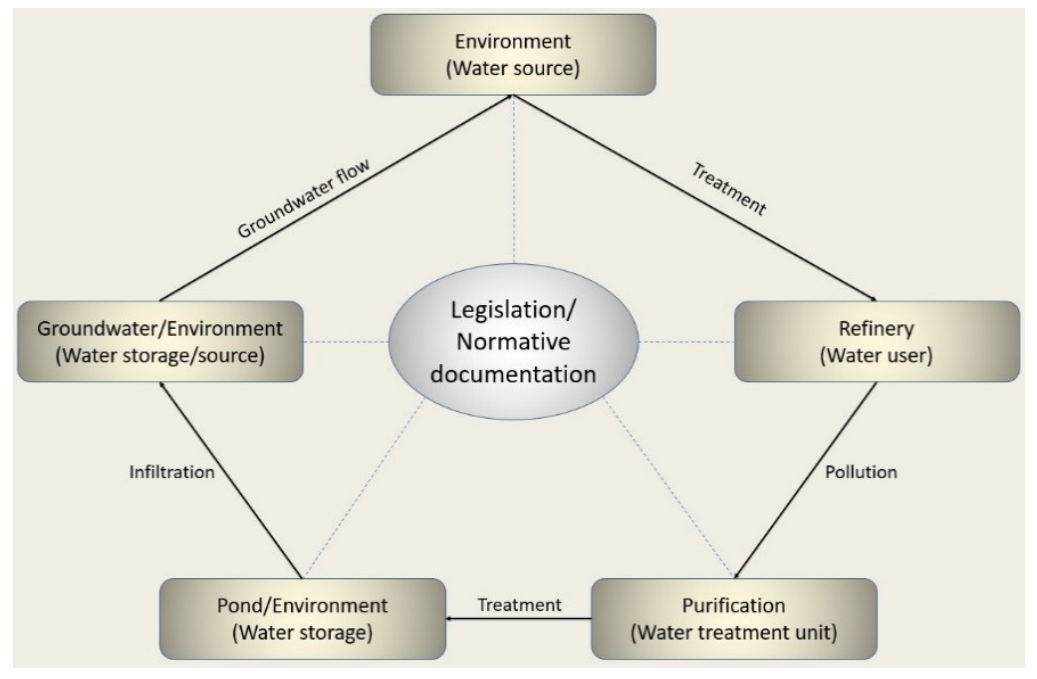

Figure 1. The existing framework for water use in oil refineries in Kazakhstan.

Thus, the study had the following objectives:

(a) Overview and compare national and international regulations in the case of water use, treatment and discharge.

(b) Investigate advanced wastewater treatment techniques as well as methods of rational water use.

(c) Assess the efficiency of wastewater treatment processes at the oil refinery factories in Kazakhstan and evaluate their influence on the environment in accordance with national and international safe water guidelines.

(d) Investigate experiences of other refineries reported in the literature concerning their implementation of tougher legislation and advanced water use methods.

(e) Suggest recommendations about possible ways to enhance each step of legislative control functions to prevent pollution and thus protect the environment and public health. 


\section{Materials and Methods}

\subsection{International and National Regulations on Water Quality}

\subsubsection{World Health Organization}

World Health Organization (WHO) is the main international office of public health and water quality. They are responsible for preventing waterborne diseases around the world. Their goal is twofold: On the one hand, they recommend suitable health care regulations to governments, which is based on a scientific approach. On the other hand, they suggest general principles of effective risk management to householders and water suppliers. WHO produces a number of water quality guidelines, including on drinking-water quality, safe use of wastewater and safe recreational water environments [9]. The authors focused on two main documents that present solutions to identify and prevent risks before water is contaminated.

The main document is the "Guidelines for Drinking-Water Quality" (GDWQ). The primary purpose of the GDWQ is the protection of public health. The guidelines should ensure the safety of drinking-water supplies through recommendations for controlling hazardous constituents in water, such as waste from agriculture, transport, industry, etc. National or regional standards should be developed from the scientific basis provided in the GDWQ. The guidelines describe reasonable minimum requirements of safe practice to protect the health of water consumers. Usually, legislative and regulatory frameworks adapt the guidelines to address local requirements and circumstances.

According to the guidelines, Chapter 8.5.2 entitled "Chemicals from industrial sources and human dwellings" [10], chemical substances from industry can reach drinking water directly from discharge systems. Another way of contamination is infiltration of materials and products through the soil. In some cases, unsuitable handling and removal of industrial wastewater may lead to groundwater pollution. The high-priority approach to prevent this pollution is to use the encouraged good treatment practices.

Moreover, there is another document from WHO on "Safe use of wastewater, excreta and greywater". The aim of this document is, firstly, to provide public health care and, secondly, to regulate the rational use of wastewater and excreta in agriculture and aquaculture. The guideline states that "in many developing countries, wastewater treatment is not a feasible option, and non-treatment approaches need to be considered to prevent transmission of pathogens or exposure to hazardous chemicals. This is more demanding on regulators, as the measures entailed vary in time and space" [11].

\subsubsection{European Union}

The following three directives are main documents about providing safe water to consumers and water environment protection in the European Union (EU): The Drinking Water Directive (98/83/EC), The Directive Concerning Urban Wastewater Treatment (91/271/EEC) and Industrial Emissions Directive (2010/75/EU). EU states that protection of the environment is based on the precautionary principle. It includes, firstly, priority treatment preventive actions and, secondly, the compulsory rule that the polluter should pay. According to the Directive Concerning Urban Wastewater Treatment [12], the process for treatment can be very expensive. Therefore, enterprises must provide development of innovative water treatment technologies to achieve safe water.

The objective of the EU Urban Wastewater Directive is to protect the environment from negative effects from urban and industrial wastewater discharges. The Directive, in Section C, Annex 1, states that industrial wastewater must be subject to such pre-treatment. This requirement ensures the environment from adverse effect of discharges from the treatment plants and prevents receiving polluted water. In accordance with other Community Directives, wastes must be safely recycled in an environmentally acceptable manner [13]. The industrial wastewater that flows to sewage systems should be subject to general regulations of treatment similar to that of urban wastewater, whereas 
discharges from certain industrial sectors of biodegradable industrial wastewater should be subject to suitable regulations before entering the recipients.

\subsubsection{Kazakhstan}

Legislation in the sphere of water resources use is regulated by four documents: (1) the "Law on the Protection of the Environment of the Republic of Kazakhstan"; (2) the "Water Code of the Republic of Kazakhstan"; (3) Order No. 209 of the Minister of National Economy of the Republic of Kazakhstan dated 16 March 2015, "Sanitary and Epidemiological Requirements for Water Sources, water intake points for household and drinking purposes, domestic and drinking water supply and places of cultural and domestic water use and water safety" with the generalized list of maximum permissible concentrations and approximately safe levels of exposure for harmful substances for water; and (4) Order No. 110 of the Minister of Environmental Protection of the Republic of Kazakhstan dated 16 April 2012 "On Approval of the Methodology for Determining norms of emissions into the environment" [14,15].

The method for calculating the maximum permissible discharges (MPD) of substances discharged from the wastewater of enterprises into storage tanks was developed for the industry. This technique contains a system of mathematical equations that allow calculating maximum concentration of pollutants for different types of wastewater. This water is discharged into special natural or artificial water storage facilities. The calculation algorithm considers the natural, climatic and hydrogeological conditions of the recipient. It also pays attention to background characteristics. According to the methodology, effluents may contain pollutants if the concentrations do not exceed the already existing concentration in the recipient [15].

\subsection{Description of the Area and the Industry}

Kazakhstan's refining sector is represented by three large oil refining enterprises. The plants were built during the Soviet Union period in different parts of the country. These factories are presented in Table 1 and Figure 2.

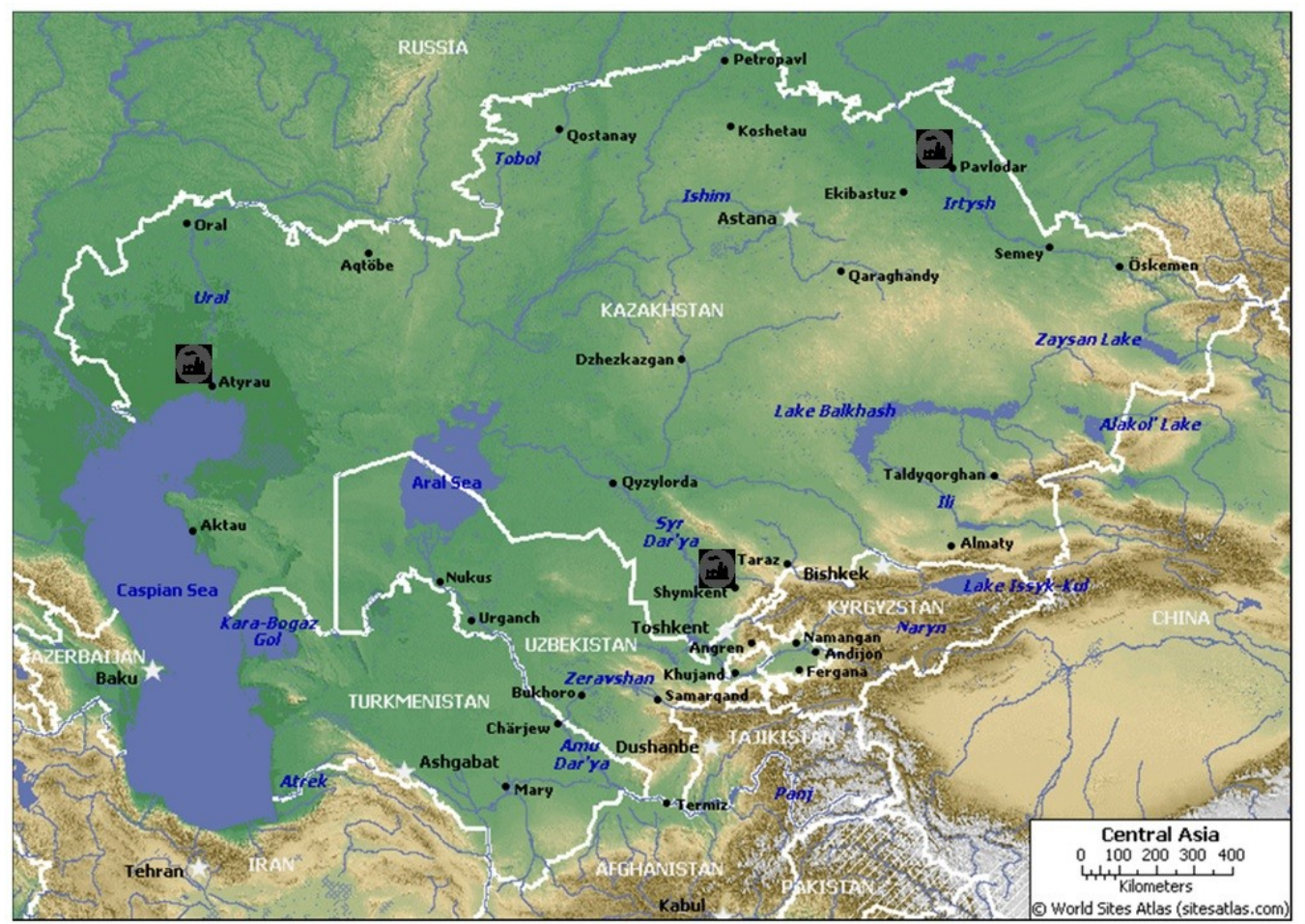

Figure 2. The locations of refinery plants in Kazakhstan. 
Table 1. Oil refining volumes in Kazakhstan's refineries in 2016 [16].

\begin{tabular}{cccc}
\hline Name & $\begin{array}{c}\text { Oil Refining Volumes, } \\
\text { Million Tons per Year }\end{array}$ & $\begin{array}{c}\text { Oil Refining Capacity, } \\
\text { Million Tons per Year }\end{array}$ & $\begin{array}{c}\text { Processing Depth } \\
\text { (Conversion Ratio), \% }\end{array}$ \\
\hline "Atyrau Refinery" (AR) & 4.491 & 5.0 & 65.2 \\
\hline $\begin{array}{c}\text { "PetroKazakhstan Oil } \\
\text { Products" (PKOP) }\end{array}$ & 4.272 & 5.3 & 75.4 \\
\hline $\begin{array}{c}\text { "Pavlodar PC Plant" } \\
\text { (PPCP) }\end{array}$ & 4.036 & 5.1 & 76.6 \\
\hline
\end{tabular}

Modern Kazakhstani refineries are sophisticated complexes for separating and modifying crude oil into different products. The general scheme is presented in Figure 3. The main objective is production of fuel, residual fuel oils, lubricants and many other petrochemical and chemical products. The initial refinery configuration was the topping refinery, which was designed to distil crude oil into a limited range and yield of products. It was composed of different units such as tankage, atmospheric and vacuum distillation units, recovery facilities for gases and light hydrocarbons, and the necessary utility systems such as steam, power, and water-treatment plants. The addition of hydrotreating and reforming units to this basic configuration resulted in a more efficient hydroskimming refinery, which produced desulfurized distillate fuels and high-octane gasoline. At the same time, refineries processed up to half of incoming crude oil. During the last 30 years all three refineries were modernized. Initially, a gas-oil conversion plant and a catalytic cracking unit were added. In the last five years, an olefin conversion plant, a polymerization unit and coke calcination units were implemented in the existing scheme of plants. The changes allow enterprises to increase processing depth and thereby produce large outputs of gasoline with the remainder of their products distributed among liquefied petroleum gas, jet fuel, diesel fuel and a small quantity of coke. Additionally, refineries also supply different substances, such as propylene, benzene, toluene, xylenes, etc., for further processing into polymers [17-19].

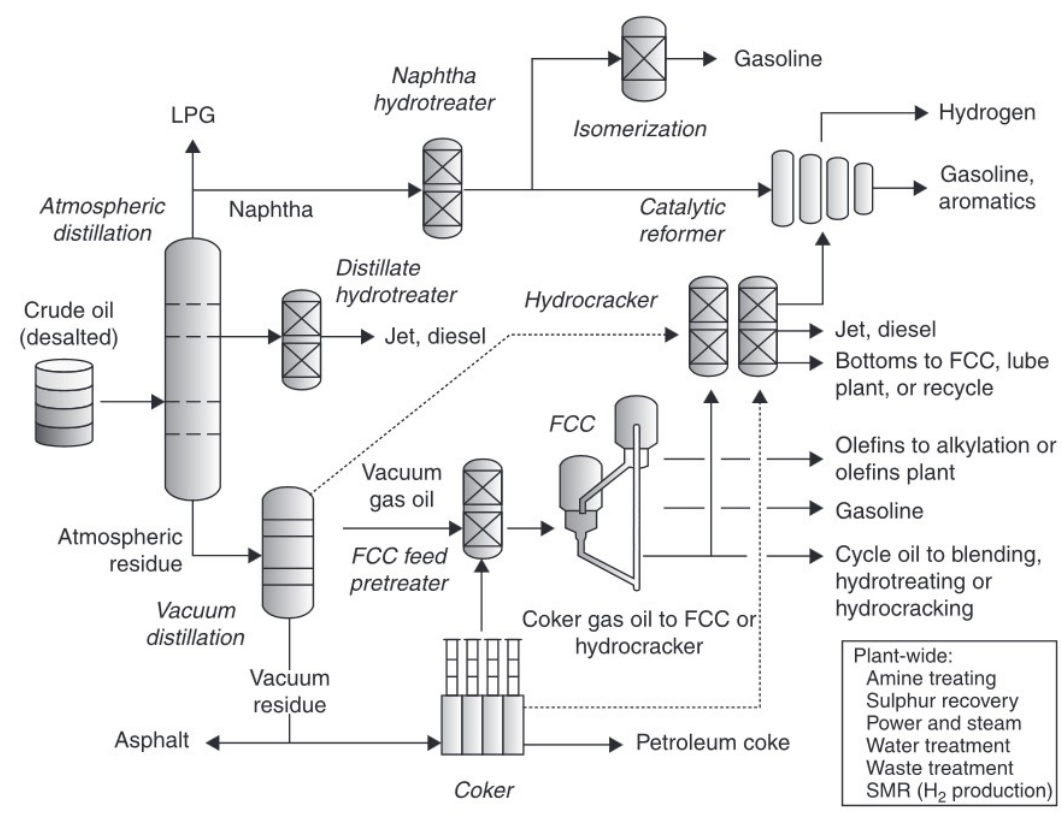

Figure 3. General scheme of an oil refinery plant [20]. LPG, Liquefied Petroleum Gas; FCC, Fluid Catalytic Cracking Unit. 


\subsection{Use of Water for Technological Purposes}

The water supply system of an oil refinery is a whole complex of several different sub-systems. The scheme depends on the technological units' purpose and the quality of the incoming water as well as the composition of the generated wastewater. The amount of water consumed by the process units depends on the specific technology of the oil processing or crude oil fractions [21,22].

The supplied water must be suitable for production needs and satisfy the requirements by qualitative characteristics. Usually, water is received from available open sources or from the drinking water pipelines. These types of water can be easily adapted to appropriate quality. The incoming water quality indicators often exceed the permissible values, e.g., turbidity, suspended solids, iron, manganese, etc. Thus, pre-cleaning is needed to produce an adequate water quality. In Kazakhstan, factories obtain water for technical processes from the large rivers: Irtysh River (PPCP), Ural River (AR) and Badam River (a tributary of Arys River, PKOP).

The oil refining process starts in the atmospheric and vacuum distillation units. Those units are associated with the consumption of several by-products and reagents, including water, which is used for various purposes, for instance as a cooler of process units and equipment, and a cooling agent of the final product. Water is also used as a solvent for the preparation of reagent solutions as well as a source of steam or condensate. Furthermore, other reagents are added during a technological process, such as demulsifiers for dehydration of oil, ammonia to neutralize organic acids and sulfur compounds for treatment of light distillates.

There are three main sources of wastewater contamination at the refinery: (1) recycling of sulfurous oil and treatment of petroleum products with alkalines, which gives highly concentrated sulfurous alkaline wastewater; (2) complex processing of oil and gas to produce synthetic products generates wastewater with organic acids, alcohols, phenols, etc.; and (3) processes of desalination and dehydration. In the final source, wastewater contains demulsifiers and sulfonaphthones. All these substances are sources of harmful production, which leads to environmental pollution [23-26].

It is necessary to emphasize the harmfulness of some chemicals. Oily wastewater consists of hundreds of organic and inorganic compounds, some of which severely jeopardize the environment. Effluents include aromatic hydrocarbons, which have high toxicity and a stable structure. These include polycyclic aromatic hydrocarbons (PAH), which affect both the environment and human health. Carcinogenic, teratogenic and mutagenic properties were investigated and presented by different authors [27]. Degradation of PAH is a very difficult process, which leads to their high persistence in the environment. Another group of hydrocarbons in contaminated water is BTEX (benzene, toluene, ethylbenzene and xylenes). High concentration of those compounds can be rapidly absorbed by the human body. They can lead to damage of the brain and nervous system, rapid heart rate, dizziness and unconsciousness. The long time effect of consumption of even low concentrations may cause cancer [28]. Phenols are considered very hazardous for human health [29]. Heavy metals such as chromium, iron, nickel, copper, molybdenum, selenium, vanadium and zinc can also be found in wastewater from oil refineries [30].

\subsection{Wastewater Treatment Technology Review}

In an oil refinery, wastewater treatment cleans processed water, stormwater, and sewage. Contaminated water flows from every technological unit. Water can be polluted in the facilities that produce wash water, condensate, liquids from stripping unit, and caustic and neutralization acids. The wastewater contains suspended solids, dissolved salts, oil and grease, nitrogen compounds, organic sulfides, and other substances [26].

Conventional treatment schemes include broad variations for each step of treatment: pre-treatment, primary, tertiary (secondary) and post-treatment. The following reviews and investigations show innovative ways to enhance each part of the whole process. Figure 4 presents the conventional scheme of wastewater treatment unit at refinery enterprises. 


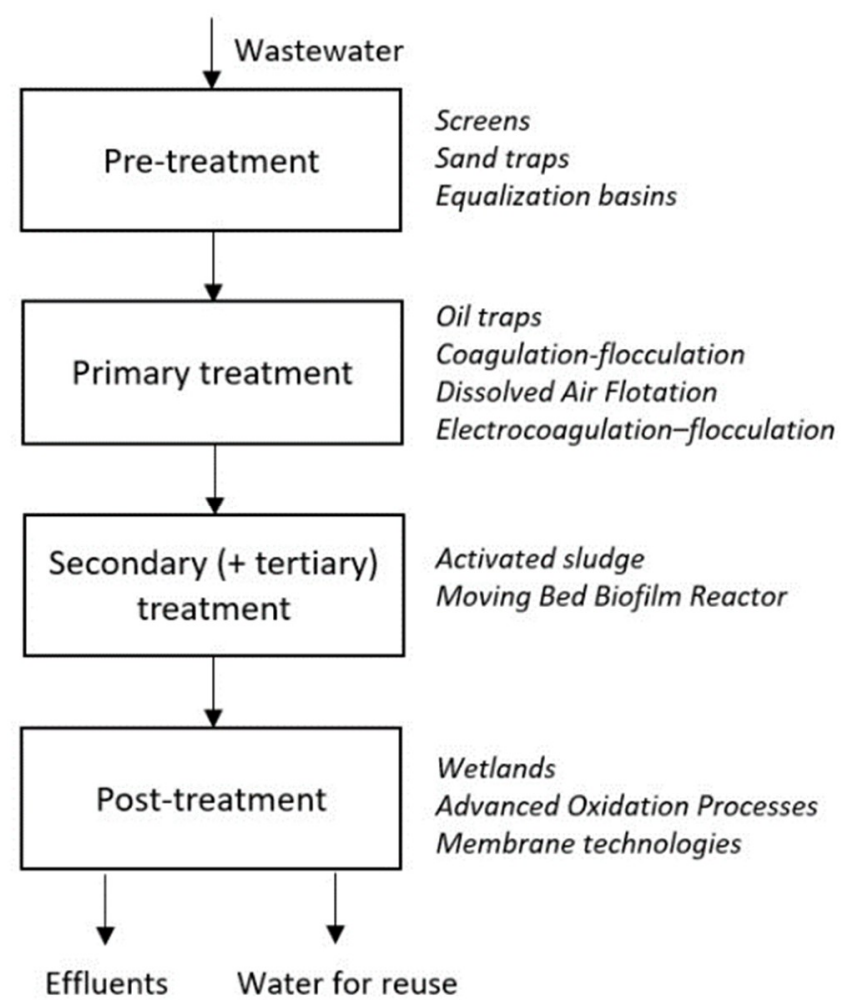

Figure 4. General scheme of wastewater treatment processes at oil refineries.

\subsubsection{Primary Treatment}

Settling ponds are used as a first step in the treatment process. Here, a majority of suspended solids are separated from the wastewater under the action of gravity and settle on the bottom. Oil and grease are floated on the surface and removed with the sludge. Heat is supplied to accelerate the removal of insoluble heavy oily emulsions. After that, precipitation of different chemicals is used for removing dissolved solids. Wastewater with high concentration of acids is treated by ammonia, lime, or sodium carbonate. Alkaline wastewater is treated with acids (usually sulfuric or hydrochloric), or carbon dioxide gas. Sometimes additional treatment of suspended solids is needed. Precipitation of flocculation agents (aluminum or iron salts) is used to agglomerate small particles and make them heavier or lighter, depending on the treatment method: sedimentation, filtration or air flotation. Soluble organic matters are removed with activated sludge digests. It is possible to decompose sulfides and ammonia by vaporization. Soluble hydrocarbons and their derivatives, especially phenols, are removed by solvents.

To enhance the efficiency of this step, Santo et al. [31] suggested using dissolved air flotation (DAF). This method was first used in the oil refinery industry in Egypt [32,33]. Spraying air into water or bubbling air through the water removes remaining traces of volatile chemicals such as petroleum hydrocarbons and ammonia. Significant removal of total organic carbon (TOC), chemical oxygen demand (COD) and turbidity was achieved. Advantages of this application are easy operation and low space requirement.

In addition, electrocoagulation-flocculation has been combined with the traditional method for primary treatment. Several different industries have successfully applied this method [34-37]. As a result of electrolysis, charged particles are neutralized in raw wastewater and subsequently form flocs. It is possible to remove phenol, anions such as nitrate and nitrite, cations such as ammonia, and metals as well as COD, TOC, color and turbidity [35,38-42]. This method has been implemented for a pilot project at Shazand Oil Refinery in Arak, Iran [43]. This method is recommended as a high-speed, non-expensive and environmentally friendly. 


\subsubsection{Secondary (Tertiary) Treatment}

Some reviews describe tertiary treatment methods [26,44,45]. Traditional activated sludge system with aerobic and anaerobic zones are usually enhanced by different applications. One common application is MBBR (Moving Bed Biofilm Reactor). An aeration tank is filled with wastewater after pretreatment and consists of special plastic carriers with growing bacteria on their surface. The biodegradation process is resistant to toxic and shock loads. Drawbacks of this method are hard to operate a process and high cost. In addition, high energy requirement and production of polluted sludge may affect to the environment. However, this method shows high efficiency for removal COD, TOC and nitrogen compounds. Several scientists reported about using this method at petroleum refineries in Sweden, USA and India [46-48].

\subsubsection{Post-Treatment}

Additional treatment removes specific pollutants, including salinity, organic matters, BTEX and other partially soluble hydrocarbons, such as PAH. Recently, sustainable schemes of wastewater treatment also implement a post-treatment step, including membrane technologies, advanced oxidation processes and wetlands [18,26,49-53].

Munirasu et al. [54], Alzahrani et al. [55] and Gong et al. [56] presented detailed reviews of the use of membrane technology. Depending on pore size, different membrane technologies are defined: microfiltration (MF), ultrafiltration (UF), nanofiltration (NF) and reverse osmosis (RO). Different methods are chosen for specific demands of raw water quality and output water requirements. The authors of [57-60] showed the effectiveness of these process for oily wastewater, even at large industrial scale. On the other hand, high amounts of contaminants clog the membrane, which leads to high cleaning cost for constantly changing them. A refinery could use this method if potential benefits from implementation are higher than expenditure.

Advanced oxidation processes (AOP) are suggested to solve the problem of removing hard-degradable organic matters. Hydroxyl radical $(\bullet \mathrm{OH})$ is produced to provide a high oxidation potential, which destroys organic molecules in wastewater [61]. To initialize this reaction, ultrasound, ozonation, photocatalysis and peroxide oxidation are used [62-65]. One of the most popular AOP methods is Fenton's reaction, based on using $\mathrm{Fe}^{2+}$ in an acidic aqueous environment to produce hydroxyl radical [66-68]. Recently, this treatment method has been enhanced by different authors to overcome existing disadvantages: the $\mathrm{pH}$ dependency and temperature variability [69-72].

Finally, probably the most famous post-treatment method is wetland use. Currently, oil refinery countries use wetlands for wastewater post-treatment. Previously, wetlands were constructed only for domestic water treatment. Therefore, for the last 20 years, wetlands have been applied to industrial wastewater treatment [73]. There are many examples and many reviews of successful application of wetlands for oil refinery wastewater treatment [74-83]. However, certain climatic conditions are required to sustain the wetland systems, e.g., Wang, et al. [84] showed that wetlands do not function well during the cold season.

\subsubsection{Wastewater Reuse}

Application of advanced treatment methods assumes that treated wastewater has to be reused. Different variations of water saving techniques are proposed for refinery enterprises in Brazil [85,86], Iran [87,88], Netherlands [89], Mexico [90], USA [91], Romania [92], China [93] and Australia [85]. There are two main approaches, which should be combined: modeling of sufficient water network allocation and suitable treatment methods for each case.

Historically, El-Halwagi and Manousiouthakis [94] were the first to analyze systems of mass exchange network in the industry. Later, Wang and Smith [95] described a detailed system of optimization water use in some specific cases using graphical method. This technique includes measurement of wastewater flow generation, water consumption index and contaminants mass 
transfer within the industrial processes. It allowed only minimizing wastewater flow generation. Later, Mann and Liu [96] proposed that, in some cases, it is possible to establish regeneration units before wastewater treatment step and supply regenerated water again to the process. Bagajewicz et al. proposed modeling investigations for the implementation of water reuse system towards zero discharge policy $[97,98]$. Alva-Argaez presented conceptual work about cost and optimization efficiency for oil refineries [23]. Finally, an appropriate treatment method has to be suggested for each case. After treatment, recycled water can be reused again as a process water for every unit inside the factory.

\subsection{Wastewater Treatment Technology in Kazakhstani Refineries}

All factories in Kazakhstan use the same wastewater treatment systems, consisting of on-site mechanical (as a primary step) and biological (as a secondary step) treatment. It should be noted that the biological treatment systems of PPCP and PKOP were built during the Soviet Union period and now are in urgent need of modernization. Moreover, there is a significant time gap between when the plants started to operate and the implementation of the biological treatment: PPCP started production 1978, while the biological treatment facilities were built in 1981; and AR started its production in 1945, while the biological wastewater treatment plant was not built until 2006.

The existing scheme in Kazakhstani factories includes two unrelated systems, divided by the content of the contaminants. The first system is represented by conditionally "neutral" effluents contaminated with oil products and mechanical impurities from the primary processing unit, deep processing oil complex, hydrogen production plant, sulfur production plant, bitumen production plant, washing and steaming station, commodity-raw parks, and stormwater from the territory of the plant. This water is considered conditionally clean, and after treatment is reused in the cooling towers. The second system includes wastewater from effluents of desalination and dehydration units, sulfurous alkaline wastes from the blocks of alkalization, drainage from the pits, discharges after flushing from the loading piers, wastewater after flushing and steaming station, and process condensate. After treatment, this water is fed to the evaporation storage tank. Both waters pass through the same steps of treatment but in parallel processes [99].

The technology of wastewater treatment at PPCP is presented as an example of the treatment facilities in Kazakhstani plants in Figure 5.

Mechanical wastewater treatment is designed to separate undissolved mineral and organic impurities by the method of settling wastewater. Initially, wastewater flows through the sand trap for filtration. Oil floats to the surface of water and is separated by the oil separating trap. At the same time, the concentrations of pollutants in wastewater is reduced to a value where it is possible to perform physical and chemical treatment in the radial settling basins and flotators. Physicochemical treatment is intended to remove fine and colloidal particles of petroleum products and mechanical impurities from the wastewater. The coagulant (aluminiumsulfate) is added to the wastewater. It produces and strengthens aggregates of particles of the colloidal system. These adhering aggregates of contaminants are removed in the flotators when air bubbles and wastewater are separated into phases. The wastewater, treated by physicochemical method, is supplied to the biological treatment facilities for further treatment.

The biological treatment facilities include three parts: (1) aerotanks, where wastewater is continuously mixed with an activated sludge and aerated until oxygen saturates the air; (2) radial sedimentation tanks are intended to separate the sludge mixture into clarified water and activated sludge; and (3) the bioproducts are intended for post-treatment of wastewater of the second system. 


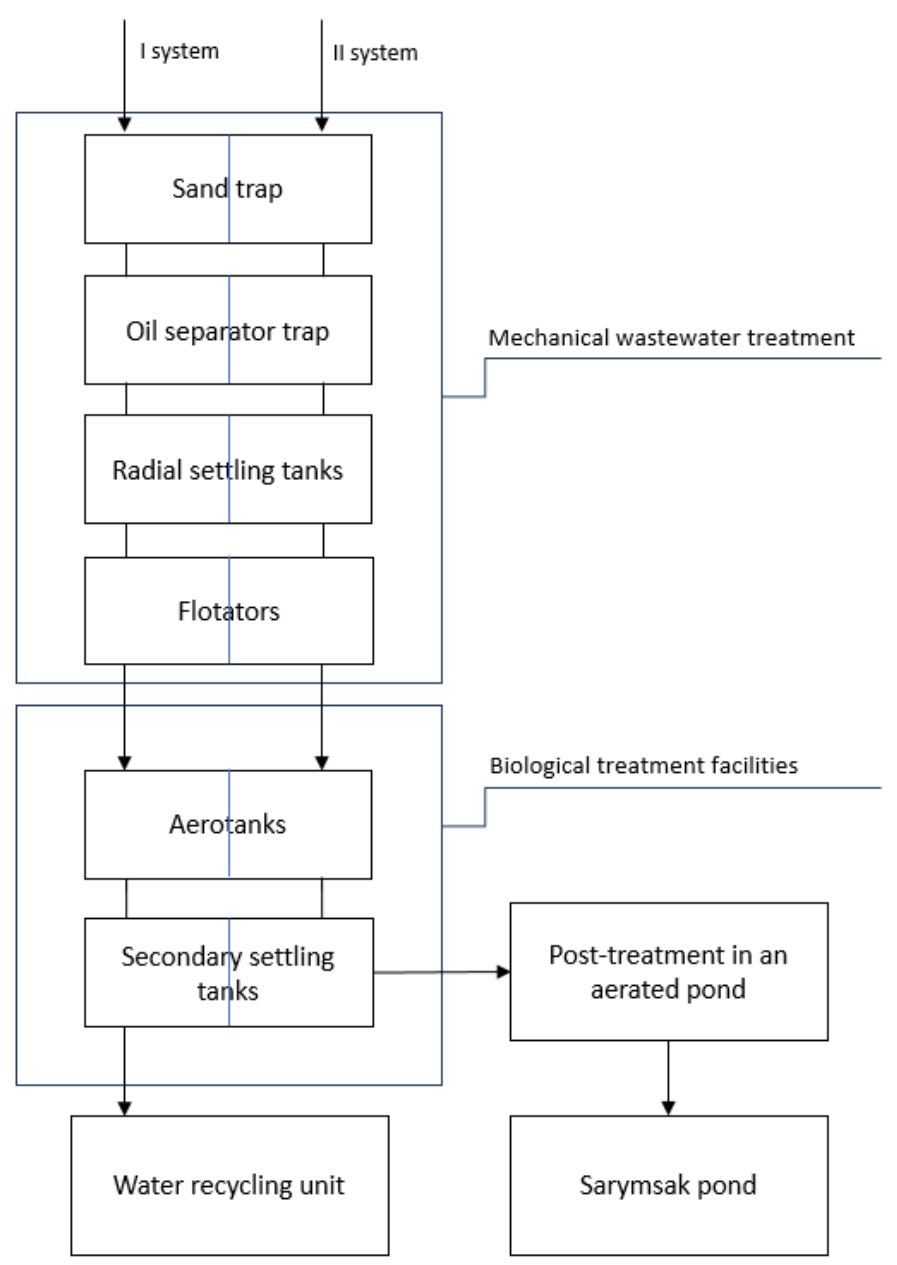

Figure 5. The block diagram of wastewater treatment processes at PPCP.

The operation principle of the biological wastewater treatment plants is based on the oxidation of organic pollutants due to activity of microorganisms in active silt under intensive aeration. Active sludge adsorbs and oxygenates a significant part of the contaminants. Organic substances in wastewater (organic acids, alcohols, proteins, carbohydrates, etc.) feed microorganisms in an active sludge. The microorganisms obtain the nitrogen, phosphorus and potassium necessary for life from various compounds: nitrogen from ammonia, nitrates, and amino acids; and phosphorus and potassium from mineral salts. One part of pollutants is oxidized by microorganisms. After that, it is used in biosynthesis processes (formation of the active sludge biomass). The other part is converted into other oxidation products: water, carbon dioxide, nitrate-sulfate ions, etc. [100].

\subsection{Final Discharge of Treated Wastewater}

There is a different approach to the final disposal of treated wastewater at all three Kazakhstani plants.

AR sends effluent after the biological treatment through a channel to the existing natural evaporation pond, located $3 \mathrm{~km}$ from the plant. The channel starts at the plant, runs along the southeastern border of the city and ends in an unprotected evaporation pond. The area of the pond is $10 \mathrm{~km}^{2}$. It is located $1.5 \mathrm{~km}$ southeast of the city boundary and $10 \mathrm{~km}$ from the Caspian Sea.

In PKOP, the wastewater after treatment and mixing with drinking water is discharged into the Akdalinsky evaporation pond, located $96 \mathrm{~km}$ from the plant through the buffer channels. Buffer channels are open reservoirs formed by excavation of the soil, which is covered with reinforced 
concrete with waterproofing. This pond is connected with the Arys River, the main water source for agriculture fields in the south part of Kazakhstan.

PPCP uses a pipeline to deliver effluents to Sarymsak pond. This storage area, originally a natural salt lake, is used for receiving, storing, mineralizing and unloading biologically treated wastewater from PPCP. There are no water intakes, recreation and bathing areas, or agriculture near its location. The pond is located $14 \mathrm{~km}$ to the northwest of the plant and covers an area of 606.1 ha. There are two villages around the pond: Berezovka village in $2.5 \mathrm{~km}$ to the north and Michurino village in $8 \mathrm{~km}$ to the northwest. The main water source in Kazakhstan-Irtysh River-is located $9 \mathrm{~km}$ to the west from the pond.

\section{Results and Discussion}

The data employed include gathered documentation and lab results from three oil refinery companies. Enterprises were denoted as " $\mathrm{X}$ ", " $Y$ " and " $Z$ ", to protect their confidence and use available data only for scientific purposes. Data from Refinery " $X$ " were used as an example to show a system of wastewater management at Kazakhstani enterprises.

Discharge limits for each oil refinery were established separately between the plant and the government. This allows the factory to determine the quality parameters of wastewater (Table 2). When the permissible concentrations of pollutants in discharging wastewater were established, calculation approach was based on the following two facts: (1) projected and actual purposes of the recipient-reception and accumulation of wastewater from the plant—which means that pond is not used as a source of water for agricultural and domestic purposes; and (2) it is possible to discharge polluted wastewater with existing concentrations of different contaminants, if those concentrations do not exceed the permissible values in the pond. The reason for the already high concentrations of pollutants in the recipient is a result of a time difference between the start of contaminated water discharge by the factories and start of the work of treatment units.

Table 2. Maximally permitted concentrations of different parameters in effluent of three Kazakhstan oil refineries [100-102].

\begin{tabular}{|c|c|c|c|c|}
\hline Parameter & Units & Refinery X & Refinery $Y$ & Refinery $\mathrm{Z}$ \\
\hline Ammonia $\left(\mathrm{NH}_{4}^{+}\right)$ & $\mathrm{mg} / \mathrm{L}$ & 55.18 & 8.0 & 4.53 \\
\hline Total petroleum hydrocarbons (TPH) & $\mathrm{mg} / \mathrm{L}$ & 3.02 & 8.0 & 2.03 \\
\hline $\begin{array}{l}\text { Biochemical consumption of Oxygen } \\
\text { (BOD) }\end{array}$ & $\mathrm{mgO}_{2} / \mathrm{L}$ & 17.82 & 16.6 & 11.6 \\
\hline Nitrates $\left(\mathrm{NO}_{3}^{-}\right)$ & $\mathrm{mg} / \mathrm{L}$ & 19.2 & 7.8 & 8.96 \\
\hline Nitrites $\left(\mathrm{NO}_{2}^{-}\right)$ & $\mathrm{mg} / \mathrm{L}$ & 7.7 & 0.5 & - \\
\hline Sulfates $\left(\mathrm{SO}_{4}{ }^{2-}\right)$ & $\mathrm{mg} / \mathrm{L}$ & 643.05 & 500.0 & 471.1 \\
\hline Phenol's index & $\mathrm{mg} / \mathrm{L}$ & 0.25 & 0.05 & 0.182 \\
\hline Chlorides $\left(\mathrm{Cl}^{-}\right)$ & $\mathrm{mg} / \mathrm{L}$ & 169.8 & 350.0 & 678.8 \\
\hline Suspended solids & $\mathrm{mg} / \mathrm{L}$ & 20.98 & 25.75 & 6.05 \\
\hline Surfactants & $\mathrm{mg} / \mathrm{L}$ & 0.52 & 2.80 & 1.27 \\
\hline Phosphates $\left(\mathrm{PO}_{4}^{3-}\right)$ & $\mathrm{mg} / \mathrm{L}$ & 1.05 & 2.0 & 6.89 \\
\hline Total Dissolved Solids (TDS) & $\mathrm{mg} / \mathrm{L}$ & $\begin{array}{l}\text { Existing } \\
\text { concentration }\end{array}$ & 6000 & - \\
\hline
\end{tabular}

Table 3 presents the characteristics of wastewater effluents discharged from Refinery X during the period between 2014 and 2017. Measurements were provided twice a day, every day and analyzed in the lab of the factory. Factory discharges the wastewater with the ammonia concentration approximately $50 \mathrm{mg} / \mathrm{L}$, while the normal concentration of ammonia for municipal effluents is equal to no more than $2.0 \mathrm{mg} / \mathrm{L}$. The same situation is found for TPH. The concentration of TPH in effluents is about $1.2 \mathrm{mg} / \mathrm{L}$, when the limit for the concentration in treated municipal wastewater is $0.1 \mathrm{mg} / \mathrm{L}$. 
The concentration of BOD is about $10.6 \mathrm{mgO}_{2} / \mathrm{L}$, when allowed concentration for safe water is no more $3.0 \mathrm{mgO}_{2} / \mathrm{L}$.

Table 3. Concentrations of different parameters in effluent of Refinery X.

\begin{tabular}{cccccc}
\hline Parameter & Units & Range & Median & Mean & Std. Deviation \\
\hline Chlorides $\left(\mathrm{Cl}^{-}\right)$ & $\mathrm{mg} / \mathrm{L}$ & $49.80-135.04$ & 70.61 & 82.48 & 26.47 \\
Nitrites $\left(\mathrm{NO}_{2}{ }^{-}\right)$ & $\mathrm{mg} / \mathrm{L}$ & $0.08-4.37$ & 0.43 & 0.10 & 1.27 \\
Sulfates $\left(\mathrm{SO}_{4}{ }^{-}\right)$ & $\mathrm{mg} / \mathrm{L}$ & $238.32-588.73$ & 469.50 & 449.04 & 90.98 \\
Nitrates $\left(\mathrm{NO}_{3}{ }^{-}\right)$ & $\mathrm{mg} / \mathrm{L}$ & $1.77-16.41$ & 13.23 & 12.49 & 3.96 \\
Ammonia $\left(\mathrm{NH}_{4}{ }^{+}\right)$ & $\mathrm{mg} / \mathrm{L}$ & $38.56-54.34$ & 52.36 & 49.26 & 5.97 \\
Total Petroleum Hydrocarbons (TPH) & $\mathrm{mg} / \mathrm{L}$ & $0.68-2.15$ & 1.23 & 1.30 & 0.40 \\
Phenol's index & $\mathrm{mg} / \mathrm{L}$ & $0.01-0.03$ & 0.02 & 0.02 & 0.01 \\
Suspended solids & $\mathrm{mg} / \mathrm{L}$ & $4.40-9.10$ & 7.69 & 7.29 & 1.35 \\
Surfactants & $\mathrm{mg} / \mathrm{L}$ & $0.20-0.45$ & 0.36 & 0.34 & 0.08 \\
Biochemical oxygen demand (BOD) & $\mathrm{mgO}_{2} / \mathrm{L}$ & $8.51-13.12$ & 10.56 & 10.60 & 1.48 \\
\hline
\end{tabular}

As a result, enterprises cause significant damage to the environment. This is reflected in an infiltration of pollutants into the groundwater. According Kazakhstani Sanitary and epidemiological requirements for water sources, groundwater could be used for non-centralized drinking water supply; this is especially relevant because about half the rural population uses decentralized water sources and about $40 \%$ of population live in rural areas in Kazakhstan [103,104]. Thus, the government established this standard for groundwater quality in observation wells to eliminate risk of groundwater pollution and prevent public health hazards. Concentrations of hazardous material are established the same way as for drinking water [105]. Some chemical parameters are exceeded in the observed wells' samples around the wastewater receiver pond of Refinery X (Table 4). This situation leads to potential threat of human health. In total, 35 samples from 9 wells were collected and analyzed between 2015 and 2016, during both the rainy and the dry season.

Table 4. Descriptive statistics of groundwater quality * from observed wells around the water facility storage area of Refinery X.

\begin{tabular}{ccccc}
\hline Parameter & Units & $\begin{array}{c}\text { KZ, WHO } \\
\text { Standards [10,105] }\end{array}$ & Range & Mean \\
& & 350.0 & $15.00-16,000.00$ & 2201.33 \\
Deviation
\end{tabular}

"-": not controlled; *: standards for drinking water when groundwater can be used for drinking purposes.

High concentrations of TPH, TDS, TH, chlorides, sulfates, sodium and potassium were detected in the observed wells around the water storage facilities. There were high concentrations of TPH and TDS in all wells, which exceeded KZ- and WHO-recommended limits for these substances. 
Some studies show that consumption of water with TPH may lead to carcinogenic disease by the reason of inherent toxicity $[30,106,107]$. The TH in the groundwater samples varied between 3.65 and $377.50 \mathrm{mmol} / \mathrm{L}$. Based on the Todd classification, all groundwater samples could be classified as very hard [108]. The $\mathrm{Cl}^{-}$concentrations were between 15.0 and 16,000 mg/L, with most groundwater samples exceeding WHO's $350 \mathrm{mg} / \mathrm{L}$ permissible limit. In addition, $\mathrm{SO}_{4}{ }^{2-}$ concentrations exceeded the limit by 19 times. There is a possible health-related concerns regarding $\mathrm{K}^{+}$and $\mathrm{Na}^{+}$content in the groundwater because concentrations in wells was over permissible WHO and KZ limits. Finally, randomly exceeding concentrations of surfactants, $\mathrm{NO}_{2}{ }^{-}, \mathrm{NO}_{3}{ }^{-}$, and $\mathrm{NH}_{4}{ }^{+}$were identified. Consumers normally would reject this type of contaminated water for drinking purpose in accordance of WHO recommendations [10].

More attention has to be paid to the fact that none of the factories provide control of heavy metal and toxic hydrocarbons in their effluents and monitoring wells.

\section{Summary}

Industrial effluents are potentially very harmful. They can reach groundwater and create serious damage to public health through consumption of polluted water. To be a part of global society, huge water users must follow sustainable management of water and sanitation [109]. Industry faces the challenge of rational use water by efficient wastewater treatment management.

This review shows that there are two ways to modify situation: (1) introducing efficient and innovative water use and treatment techniques; and (2) improving legislation.

Since the 1980s, some surveys and investigations have tried to find the relationship between legislation and industrial emissions to the air and water. A clear correlation between these parameters has been found. In Japan, in 1980, the impact of legislation for improvement effluent water quality was described [110]. Industry supplied their wastewater to municipal sewerage system. Government obligated the industry to install pretreatment facilities for prevention of low-quality water. Spot inspections, administrative fees and toughening of legislation led to discharge water with restricted requirements. Hamer [111] discussed the wrong opinion to respect and allow pollution of receiving water. He examined interactions among Swiss, Dutch and British legislations and industry and environment. Swiss legislation aimed to stop water pollution by 1982. For this purpose, they established strict quality parameters for discharged water by federal law. Netherlands also provided governmental authority on the sphere of water pollution and followed "polluter pays" principle. The aim of Surface Water Pollution Act was accepted to eliminate contamination. Discharge fees were provided and grew progressively every year. It led industry to use the best treatment technology to remove all pollutants from wastewater. In Great Britain, over years of long discussions, government adopted Control of Pollution Act. The enactment of this law was gradual. Economic troubles, administrative obstacles and unfair enterprises impeded the process of changes. Nevertheless, Britain reached necessary discharge quality parameters. Compared with historical experience, current EU has produced tougher legislation. This was proven by Wake [30]. She stated a reduction of total discharge in Europe for the last 40 years as well as declining rate of discharged chemicals, while the number of refineries that improved their treatment systems grew rapidly (from $23 \%$ to $91 \%$ ) for 30 years. The United States Environmental Protection Agency (EPA) firstly in 1985 proposed special guideline for petroleum refining industry [112]. This standard stated one common rules for all enterprises and proposed new technologies, including pretreatment and advanced treatment, to achieve necessary limitations of pollutants. This document is revised constantly.

There also are some published examples of violence over effluent quality by refining enterprises. Osin et al. [113] showed that oil industry in Nigeria did not follow governmental standard of effluent quality. Whereas the law proposed and adopted Environmental Guidelines and Standards for the Petroleum Industry in Nigeria, it was not implemented. Exceedances of almost all key indicators were discovered. Bandyopadhyay reviewed the efficiency of law in India [114]. Constant violations of national standards were reported. The author also noted that the law did not cover all toxic pollutants 
that can be in water. He suggested revising the current standard and toughening it. Aljuboury et al. showed that petroleum wastewater exceeded the standard limit in Oman [115].

WHO's documents state that developing countries, including Kazakhstan, do not have appropriate legislation for wastewater treatment [10]. This has been confirmed by several investigations [116,117]. It is very important to note that GDWQ values for chemicals from industrial activities does not differ from the significance in drinking water. In addition, WHO declares that it is necessary to reduce water pollution [10]. Nevertheless, enterprises in Kazakhstan increase the amount of contaminants in wastewater. However, the WHO is only an advisory organization. It suggests governments adhere to its recommendations and cannot control them. At the same time, the Council of the European Communities produces and controls the suitable legislation on water use. For example, the EU Directive Concerning Urban Wastewater Treatment does not provide separate standards for the content of pollutants in treated wastewater for enterprises in EU. Rules and standards are established for everyone. In contrast, the modern Kazakhstani legislation gives the right for industry to set their parameters for MPD much higher than those recommended by WHO.

It is significant that the standards for technical water quality are stronger than for drinking water. For instance, the amount of total petroleum hydrocarbons (TPH) must be absent for process water. In contrast, the maximum concentration of the parameter in drinking water is $0.1 \mathrm{mg} / \mathrm{L}$. The amount of total dissolved solids (TDS) is equal to $500 \mathrm{mg} / \mathrm{L}$, whereas the standard for drinking water is $1000 \mathrm{mg} / \mathrm{L}$. The total hardness (TH) value is $11.6 \mathrm{mg} / \mathrm{L}$, whereas the standard for drinking water is $14 \mathrm{mg} / \mathrm{L}$ [118]. The refineries care about the quality of incoming water, but they do not care about the quality of discharges, as shown clearly with the example of Refinery X in Tables 2 and 3. This is the violence of water balance and there is no agreement on sustainable resources use [119]. The enterprises must supply water to the environment at the same quality as they have obtained it.

The ineffectiveness of the existing administrative regulation was confirmed by the widespread violation of sanitary standards. The estimation by environmental authorities for each plant is negotiated separately between the factory and the government. Thus, the industry has received a legal permit for environmental pollution.

\section{Conclusions}

Water contamination by the industry is the result of a non-sustainable approach. According Katko and Hukka [120], a structured approach based on sustained institutional framework leads to high quality water service production through efficient water service infrastructure. We conclude that:

(a) Enforcement of legislation allowed developed countries to eliminate risks for environment and public health. It was the first step towards sustainable water use. Pressure of stringent law and high fees stimulated industry to implement innovative and high-efficient techniques of water use.

(b) The literature review shows that developing countries are on the way to minimizing potential damage to the society and nature. The practice of sustainable water use and care about saving water sources inspired conventional industrial society to improve the current situation.

(c) There is insufficient driving force represented by suitable law in Kazakhstan to enhance an efficiency of wastewater treatment at oil refinery enterprises in Kazakhstan. Low penalties and disadvantages of current legislation allows the situation to remain unchanged.

(d) The authors of this paper consider that toughening of the legislation as well as the ensuing use of new technologies in wastewater treatment systems is the only effective way to prevent potential damage to the public health of people who use groundwater as drinking water.

Author Contributions: I.R. together with K.T. and M.P. planned the whole study, and on his own collected and analyzed the data, produced initial results and wrote the first draft of the paper. The other authors equally contributed by commenting on the first draft of the paper. K.T. supervised the process of writing paper.

Funding: This research received no external funding. 
Acknowledgments: The authors appreciate the work of Ann Kull from the Academic Support Centre, Lund University, for assisting in editing the text and Zhayna Isa for assisting in collecting the data. The first author was funded by Bolashak International Scholarship Program of Kazakhstan.

Conflicts of Interest: The authors declare no conflict of interest.

\section{References and Notes}

1. Kazakhstan's Second National Communication to the Conference of the Parties of the United Nations Framework Convention on Climate Change. 2009. Available online: https://unfccc.int/resource/docs/ natc/kaznc2e.pdf (accessed on 6 March 2019).

2. Kazakhstan Stock Exchange. Oil and gas industry of the Republic of Kazakhstan. 2017. Available online: http:/ / kase.kz/files/presentations/ru/Oil_gas_november_2017.pdf (accessed on 6 March 2019).

3. BP Statistical Review of World Energy. 2017. Available online: https://www.bp.com/content/dam/bpcountry/de_ch/PDF/bp-statistical-review-of-world-energy-2017-full-report.pdf (accessed on 6 March 2019).

4. Walker, M.E.; Lv, Z.; Masanet, E. Industrial Steam Systems and the Energy-Water Nexus. Environ. Sci. Technol. 2013, 47, 13060-13067. [CrossRef] [PubMed]

5. Wangt, R.R.; Zimmerman, J. Hybrid Analysis of Blue Water Consumption and Water Scarcity Implications at the Global, National, and Basin Levels in an Increasingly Globalized World. Environ. Sci. Technol. 2016, 50, 5143-5153. [CrossRef]

6. National Report on the State of the Environment and on the Use of Natural Resources of the Republic of Kazakhstan. 2016. Available online: http://ecogosfond.kz/orhusskaja-konvencija/dostup-kjekologicheskoj-informacii/jekologijaly-zha-daj/r-orsha-an-ortany-zhaj-k-ji-turaly-ltty-bajandamalar/ (accessed on 6 March 2019).

7. Ohe, T.; Watanabe, T.; Wakabayashi, K. Mutagens in surface waters: A review. Mutat. Res.-Rev. Mutat. 2004, 567, 109-149. [CrossRef]

8. Schmoll, O.; Howard, G.; Chilton, J.; Chorus, I. Protecting Groundwater for Health: Managing the Quality of Drinking-Water Sources; IWA Publishing: London, UK, 2006; Volume 1, p. 310.

9. WHO. Drinking Water. Available online: http://www.who.int/mediacentre/factsheets/fs391/en/ (accessed on 6 March 2019).

10. WHO. Guidelines for Drinking-Water Quality, 4th ed.; WHO Press: Geneva, Switzerland, 2017.

11. WHO. Guidlines for the Safe Use of Wastewater, Excreta and Greywater, 3rd ed.; WHO Press: Geneva, Switzerland, 2006; Volume 1.

12. The Directive Amending Directives 2000/60/EC and 2008/105/EC as Regards Priority Substances in the Field of Water Policy 2013/39/EU. 2013. Available online: https:// eur-lex.europa.eu/LexUriServ/ LexUriServ.do?uri=OJ:L:2013:226:0001:0017:EN:PDF (accessed on 6 March 2019).

13. The Directive Concerning Urban Wastewater Treatment 1991/271/EEC. 1991. Available online: https:/ / eurlex.europa.eu/legal-content/EN/TXT/PDF/?uri=CELEX:31991L0271\&from=EN (accessed on 6 March 2019).

14. Nugumanova, L.; Yemelina, N.; Yugay, S.; Frey, M. Environmental Problems and Policies in Kazakhstan: Air Pollution, Waste and Water; IOS Working Papers; Leibniz-Institut für Ost- und Südosteuropaforschung (IOS): Regensburg, Germany, 2017.

15. Order No. 110 "On Approval of the Methodology for Determining Emission Standards for the Environment". 2012. Available online: http:/ / adilet.zan.kz/rus/docs/V1200007664 (accessed on 6 March 2019).

16. JSC NC “Kazmunaygas" Annual Report. 2016. Available online: http://www.kmg.kz/uploads/ AnnualReport2016FinalEng2.pdf (accessed on 6 March 2019).

17. Speight, J.G. The Refinery of the Future; Elsevier: Amsterdam, The Netherlands, 2011.

18. Kent, J.A.; Bommaraju, T.; Barnicki, S.D. Handbook of Industrial Chemistry and Biotechnology, 13th ed.; Springer: Boston, MA, USA, 2017.

19. Cherdabayev, B. 70th Anniversary of Atyrau Refinery. 2015. Available online: https://www.anpz.kz/ upload/medialibrary/5d5/5d5051bc33d70d11c9ed417654178380.pdf (accessed on 6 March 2019).

20. Robinson, P.R. Hydroconversion processes and technology for clean fuel and chemical production. In Advances in Clean Hydrocarbon Fuel Processing; Khan, M.R., Ed.; Elsevier: Amsterdam, The Netherlands, 2011.

21. Merlo, R.; Gerhardt, M.B.; Burlingham, F.; Casas, C.D.; Gill, E.; Flippin, T.H. Petroleum Refinery Stripped Sour Water Treatment Using the Activated Sludge Process. Water Environ. Res. 2011, 83, 2067-2078. [CrossRef] 
22. El-Halwagi, M.M.; El-Halwagi, A.M.; Manousiouthakis, V. Optimal-Design of Dephenolization Networks for Petroleum-Refinery Wastes. Process Saf. Environ. 1992, 70, 131-139.

23. Alva-Argaez, A.; Kokossis, A.C.; Smith, R. The design of water-using systems in petroleum refining using a water-pinch decomposition. Chem. Eng. J. 2007, 128, 33-46. [CrossRef]

24. Hafiz, A.A.; El-Din, H.M.; Badawi, A.M. Chemical destabilization of oil-in-water emulsion by novel polymerized diethanolamines. J. Colloid Interfaces Sci. 2005, 284, 167-175. [CrossRef] [PubMed]

25. Zolfaghari, R.; Fakhru'l-Razi, A.; Abdullah, L.C.; Elnashaie, S.S.E.H.; Pendashteh, A. Demulsification techniques of water-in-oil and oil-in-water emulsions in petroleum industry. Sep. Purif. Technol. 2016, 170, 377-407. [CrossRef]

26. Yu, L.; Han, M.; He, F. A review of treating oily wastewater. Arab. J. Chem. 2017, 10, S1913-S1922. [CrossRef]

27. Alegbeleye, O.O.; Opeolu, B.O.; Jackson, V.A. Polycyclic Aromatic Hydrocarbons: A Critical Review of Environmental Occurrence and Bioremediation. Environ. Manag. 2017, 60, 758-783. [CrossRef] [PubMed]

28. Leusch, F.; Bartkow, M. A Short Primer on Benzene, Toluene, Ethylbenzene and Xylenes (BTEX) in the Environment and in Hydraulic Fracturing Fluids. Available online: https: / environment.des.qld.gov.au/ management/coal-seam-gas/pdf/btex-report.pdf (accessed on 6 March 2019).

29. Huang, J.H.; Wang, X.G.; Jin, Q.Z.; Liu, Y.F.; Wang, Y. Removal of phenol from aqueous solution by adsorption onto OTMAC-modified attapulgite. J. Environ. Manag. 2007, 84, 229-236. [CrossRef]

30. Wake, H. Oil refineries: A review of their ecological impacts on the aquatic environment. Estuar. Coast. Shelf Sci. 2005, 62, 131-140. [CrossRef]

31. Santo, C.E.; Vilar, V.J.P.; Botelho, C.M.S.; Bhatnagar, A.; Kumar, E.; Boaventura, R.A.R. Optimization of coagulation-flocculation and flotation parameters for the treatment of a petroleum refinery effluent from a Portuguese plant. Chem. Eng. J. 2012, 183, 117-123. [CrossRef]

32. Ela, S.I.A.-E.; Nawar, S.S. Treatment of wastewater from an oil and soap factory via dissolved air flotation. Environ. Int. 1980, 4, 47-52. [CrossRef]

33. Moursy, A.S.; EI-Ela, S.E.A. Treatment of oily refinery wastes using a dissolved air flotation process. Environ. Int. 1982, 7, 267-270. [CrossRef]

34. Demirbas, E.; Kobya, M. Operating cost and treatment of metalworking fluid wastewater by chemical coagulation and electrocoagulation processes. Process Saf. Environ. 2017, 105, 79-90. [CrossRef]

35. Lu, J.; Li, Y.; Yin, M.X.; Ma, X.Y.; Lin, S.L. Removing heavy metal ions with continuous aluminum electrocoagulation: A study on back mixing and utilization rate of electro-generated $\mathrm{Al}$ ions. Chem. Eng. J. 2015, 267, 86-92. [CrossRef]

36. Gong, C.H.; Shen, G.; Huang, H.O.; He, P.R.; Zhang, Z.G.; Ma, B.Q. Removal and transformation of polycyclic aromatic hydrocarbons during electrocoagulation treatment of an industrial wastewater. Chemosphere 2017, 168, 58-64. [CrossRef]

37. Bouamra, F.; Drouiche, N.; Ahmed, D.S.; Lounici, H. Treatment of Water Loaded With Orthophosphate by Electrocoagulation. Procedia Eng. 2012, 33, 155-162. [CrossRef]

38. Zewail, T.M.; Yousef, N.S. Chromium ions $\left(\mathrm{Cr}^{6+} \& \mathrm{Cr}^{3+}\right)$ removal from synthetic wastewater by electrocoagulation using vertical expanded Fe anode. J. Electroanal. Chem. 2014, 735, 123-128. [CrossRef]

39. Abdelwahab, O.; Amin, N.K.; El-Ashtoukhy, E.S.Z. Electrochemical removal of phenol from oil refinery wastewater. J. Hazard. Mater. 2009, 163, 711-716. [CrossRef]

40. Li, X.D.; Song, J.K.; Guo, J.D.; Wang, Z.C.; Feng, Q.Y. Landfill leachate treatment using electrocoagulation. Procedia Environ. Sci. 2011, 10, 1159-1164. [CrossRef]

41. Lacasa, E.; Canizares, P.; Saez, C.; Fernandez, F.J.; Rodrigo, M.A. Removal of nitrates from groundwater by electrocoagulation. Chem. Eng. J. 2011, 171, 1012-1017. [CrossRef]

42. Garcia-Garcia, A.; Martinez-Miranda, V.; Martinez-Cienfuegos, I.G.; Almazan-Sanchez, P.T.; Castaneda-Juarez, M.; Linares-Hernandez, I. Industrial wastewater treatment by electrocoagulationelectrooxidation processes powered by solar cells. Fuel 2015, 149, 46-54. [CrossRef]

43. Shahriari, T.; Karbassi, A.R.; Reyhani, M. Treatment of oil refinery wastewater by electrocoagulationflocculation (Case Study: Shazand Oil Refinery of Arak). Int. J. Environ. Sci. Technol. 2018, 2018, 13762. [CrossRef]

44. Pintor, A.M.A.; Vilar, V.J.P.; Botelho, C.M.S.; Boaventura, R.A.R. Oil and grease removal from wastewaters: Sorption treatment as an alternative to state-of-the-art technologies. A critical review. Chem. Eng. J. 2016, 297, 229-255. [CrossRef] 
45. Aljuboury, D.A.; Palaniandy, P.; Aziz, H.B.A.; Feroz, S. Treatment of petroleum wastewater by conventional and new technologies-A review. Glob. Nest J. 2017, 19, 439-452.

46. Mallick, S.K.; Chakraborty, S. Treatment of synthetic refinery wastewater in anoxic-aerobic sequential moving bed reactors and sulphur recovery. J. Environ. Sci. Health Part A 2017, 52, 1257-1268. [CrossRef]

47. Basu, S. Impact of opportunity crudes on refinery desalter and wastewater treatment performance-Part 2. Hydrocarb. Process. 2018, 97, 97-100.

48. Dale, C.; Ekenber, M.; Wenta, R. Advanced biological treatment removes benzene, phenol from refinery wastewater. Hydrocarb. Process. 2018, 97, 79-80.

49. Diya'uddeen, B.H.; Daud, W.M.A.W.; Aziz, A.R.A. Treatment technologies for petroleum refinery effluents: A review. Process Saf. Environ. 2011, 89, 95-105. [CrossRef]

50. Qin, J.J.; Oo, M.H.; Tao, G.H.; Kekre, K.A. Feasibility study on petrochemical wastewater treatment and reuse using submerged MBR. J. Membr. Sci. 2007, 293, 161-166. [CrossRef]

51. Alkmim, A.R.; da Costa, P.R.; Moser, P.B.; Neta, L.S.F.; Santiago, V.M.J.; Cerqueira, A.C.; Amaral, M.C.S. Long-term evaluation of different strategies of cationic polyelectrolyte dosage to control fouling in a membrane bioreactor treating refinery effluent. Environ. Technol. 2016, 37, 1026-1035. [CrossRef]

52. Amaral, M.C.S.; Neta, L.S.D.; Borges, C.P.; Cerqueira, A.C.; Torres, A.P.; Florido, P.L.; Santiago, V.M.J. Treatment of refinery effluents by pilot membrane bioreactors: Pollutants removal and fouling mechanism investigation. Desalin. Water Treat. 2015, 56, 583-597. [CrossRef]

53. Fallah, N.; Bonakdarpour, B.; Nasernejad, B.; Moghadam, M.R.A. Long-term operation of submerged membrane bioreactor (MBR) for the treatment of synthetic wastewater containing styrene as volatile organic compound (VOC): Effect of hydraulic retention time (HRT). J. Hazard. Mater. 2010, 178, 718-724. [CrossRef]

54. Munirasu, S.; Abu Haija, M.; Banat, F. Use of membrane technology for oil field and refinery produced water treatment-A review. Process Saf. Environ. 2016, 100, 183-202. [CrossRef]

55. Alzahrani, S.; Mohammad, A.W. Challenges and trends in membrane technology implementation for produced water treatment: A review. J. Water Process Eng. 2014, 4, 107-133. [CrossRef]

56. Gong, C.; Yu, S.L.; Yufei, S.G.; Gu, Z.Y.; Yang, W.Z.; Ren, L.M. A Review of Ultrafiltration and Forward Osmosis:application and modification. IOP Conf. Ser. Earth Environ. 2018, 128. [CrossRef]

57. Abbasi, M.; Mirfendereski, M.; Nikbakht, M.; Golshenas, M.; Mohammadi, T. Performance study of mullite and mullite-alumina ceramic MF membranes for oily wastewaters treatment. Desalination 2010, 259, 169-178. [CrossRef]

58. Ebrahimi, A.; Ashaghi, K.S.; Engel, L.; Willershausen, D.; Mund, P.; Bolduan, P.; Czermak, P. Characterization and application of different ceramic membranes for the oil-field produced water treatment. Desalination 2009, 245, 533-540. [CrossRef]

59. Alzahrani, S.; Mohammad, A.W.; Hilal, N.; Abdullah, P.; Jaafar, O. Comparative study of NF and RO membranes in the treatment of produced water II: Toxicity removal efficiency. Desalination 2013, 315, $27-32$. [CrossRef]

60. Alzahrani, S.; Mohammad, A.W.; Hilal, N.; Abdullah, P.; Jaafar, O. Comparative study of NF and RO membranes in the treatment of produced water-Part I: Assessing water quality. Desalination 2013, 315, 18-26. [CrossRef]

61. Findik, S. Treatment of petroleum refinery effluent using ultrasonic irradiation. Pol. J. Chem. Technol. 2018, 20, 20-25. [CrossRef]

62. Stepnowski, P.; Siedlecka, E.M.; Behrend, P.; Jastorff, B. Enhanced photo-degradation of contaminants in petroleum refinery wastewater. Water Res. 2002, 36, 2167-2172. [CrossRef]

63. Talei, M.; Mowla, D.; Esmaeilzadeh, F. Ozonation of an effluent of oil refineries for COD and sulfide removal. Desalin. Water Treat. 2015, 56, 1648-1656. [CrossRef]

64. Rueda-Marquez, J.J.; Levchuk, I.; Salcedo, I.; Acevedo-Merino, A.; Manzano, M.A. Post-treatment of refinery wastewater effluent using a combination of AOPs $\left(\mathrm{H}_{2} \mathrm{O}_{2}\right.$ photolysis and catalytic wet peroxide oxidation) for possible water reuse. Comparison of low and medium pressure lamp performance. Water Res. 2016, 91, 86-96. [CrossRef]

65. Sponza, D.T.; Oztekin, R. Removals of PAHs and acute toxicity via sonication in a petrochemical industry wastewater. Chem. Eng. J. 2010, 162, 142-150. [CrossRef] 
66. Fu, F.L.; Wang, Q.; Tang, B. Fenton and Fenton-like reaction followed by hydroxide precipitation in the removal of $\mathrm{Ni}(\mathrm{II})$ from NiEDTA wastewater: A comparative study. Chem. Eng. J. 2009, 155, 769-774. [CrossRef]

67. Coelho, A.; Castro, A.V.; Dezotti, M.; Sant'Anna, G.L. Treatment of petroleum refinery sourwater by advanced oxidation processes. J. Hazard. Mater. 2006, 137, 178-184. [CrossRef]

68. Huang, D.L.; Wang, C.; Xu, P.; Zeng, G.M.; Lu, B.A.; Li, N.J.; Huang, C.; Lai, C.; Zhao, M.H.; $\mathrm{Xu}, \mathrm{J}$.J.; et al. A coupled photocatalytic-biological process for phenol degradation in the Phanerochaete chrysosporium-oxalate- $\mathrm{Fe}_{3} \mathrm{O}_{4}$ system. Int. Biodeterior. Biodegrad. 2015, 97, 115-123. [CrossRef]

69. Mohadesi, M.; Shokri, A. Evaluation of Fenton and photo-Fenton processes for the removal of p-chloronitrobenzene in aqueous environment using Box-Behnken design method. Desalin. Water Treat. 2017, 81, 199-208. [CrossRef]

70. Bustillo-Lecompte, C.F.; Kakar, D.; Mehrvar, M. Photochemical treatment of benzene, toluene, ethylbenzene, and xylenes (BTEX) in aqueous solutions using advanced oxidation processes: Towards a cleaner production in the petroleum refining and petrochemical industries. J. Clean. Prod. 2018, 186, 609-617. [CrossRef]

71. Heidari, B.; Soleimani, M.; Mirghaffari, N. The use of steel slags in the heterogeneous Fenton process for decreasing the chemical oxygen demand of oil refinery wastewater. Water Sci. Technol. 2018, 78, 1159-1167. [CrossRef]

72. Estrada-Arriaga, E.B.; Zepeda-Aviles, J.A.; Garcia-Sanchez, L. Post-treatment of real oil refinery effluent with high concentrations of phenols using photo-ferrioxalate and Fenton's reactions with membrane process step. Chem. Eng. J. 2016, 285, 508-516. [CrossRef]

73. Vymazal, J. Constructed wetlands for treatment of industrial wastewaters: A review. Ecol. Eng. 2014, 73, 724-751. [CrossRef]

74. Hawkins, W.B.; Rodgers, J.H.; Gillespie, W.B.; Dunn, A.W.; Dorn, P.B.; Cano, M.L. Design and construction of wetlands for aqueous transfers and transformations of selected metals. Ecotoxicol. Environ. Saf. 1997, 36, 238-248. [CrossRef]

75. Huddleston, G.M.; Gillespie, W.B.; Rodgers, J.H. Using constructed wetlands to treat biochemical oxygen demand and ammonia associated with a refinery effluent. Ecotoxicol. Environ. Saf. 2000, 45, 188-193. [CrossRef]

76. Moore, B.J.; Ross, S.D.; Gibson, D.; Callow, L. Constructed wetlands for treatment of dissolved phase hydrocarbons in cold climates. In Proceedings of the International Conference on Wetlands Remediation, Salt Lake City, UT, USA, 16-17 November 1999; pp. 333-340.

77. Wallace, S.D. On-site remediation of petroleum contact wastes using subsurface-flow wetlands. In Proceedings of the International Conference on Wetlands Remediation, Salt Lake City, UT, USA, 16-17 November 1999; pp. 125-132.

78. Aslam, M.M.; Malik, M.; Baig, M.; Qazi, I.A.; Iqbal, J. Treatment performances of compost-based and gravel-based vertical flow wetlands operated identically for refinery wastewater treatment in Pakistan. Ecol. Eng. 2007, 30, 34-42. [CrossRef]

79. Ji, G.D.; Sun, T.H.; Ni, J.R. Surface flow constructed wetland for heavy oil-produced water treatment. Bioresour. Technol. 2007, 98, 436-441. [CrossRef]

80. Mustapha, H.I.; van Bruggen, H.J.J.A.; Lens, P.N.L. Vertical subsurface flow constructed wetlands for the removal of petroleum contaminants from secondary refinery effluent at the Kaduna refining plant (Kaduna, Nigeria). Environ. Sci. Pollut. Res. 2018, 25, 30451-30462. [CrossRef]

81. Yang, L.; Hu, C.C. Treatments of oil-refinery and steel-mill wastewaters by mesocosm constructed wetland systems. Water Sci. Technol. 2005, 51, 157-164. [CrossRef] [PubMed]

82. Wu, S.B.; Wallace, S.; Brix, H.; Kuschk, P.; Kirui, W.K.; Masi, F.; Dong, R.J. Treatment of industrial effluents in constructed wetlands: Challenges, operational strategies and overall performance. Environ. Pollut. 2015, 201, 107-120. [CrossRef]

83. Mustapha, H.I.; van Bruggen, J.J.A.; Lens, P.N.L. Optimization of Petroleum Refinery Wastewater Treatment by Vertical Flow Constructed Wetlands Under Tropical Conditions: Plant Species Selection and Polishing by a Horizontal Flow Constructed Wetland. Water Air Soil Pollut. 2018, 229. [CrossRef]

84. Wang, M.; Zhang, D.Q.; Dong, J.W.; Tan, S.K. Constructed wetlands for wastewater treatment in cold climate-A review. J. Environ. Sci.-China 2017, 57, 293-311. [CrossRef] 
85. Pombo, F.R.; Magrini, A.; Szklo, A. An analysis of water management in Brazilian petroleum refineries using rationalization techniques. Resour. Conserv. Recycl. 2013, 73, 172-179. [CrossRef]

86. Hansen, E.; Rodrigues, M.A.S.; Aragao, M.E.; de Aquim, P.M. Water and wastewater minimization in a petrochemical industry through mathematical programming. J. Clean. Prod. 2018, 172, 1814-1822. [CrossRef]

87. Mohammadnejad, S.; Bidhendi, G.R.N.; Mehrdadi, N. Water pinch analysis in oil refinery using regeneration reuse and recycling consideration. Desalination 2011, 265, 255-265. [CrossRef]

88. Mughees, W.; Al-Ahmad, M. Application of water pinch technology in minimization of water consumption at a refinery. Comput. Chem. Eng. 2015, 73, 34-42. [CrossRef]

89. Duyvesteijn, C.P.T.M. Water re-use in an oil refinery. Desalination 1998, 119, 357-358. [CrossRef]

90. Peeters, J.G.; Theodoulou, S.L. Consider membrane technologies to treat oily wastewater. Hydrocarb. Process. 2007, 86, 81-86.

91. Puckorius, P.R.; Loretitsch, G.A.; Tvedt, T.J. Reuse water quality for chemical plants, refineries, utilities and air conditioning. In Proceedings of the Corrosion 98, San Diego, CA, USA, 22-27 March 1998.

92. Iancu, P.; Plesu, V.; Lavric, V. Regeneration of internal streams as an effective tool for wastewater network optimisation. Comput. Chem. Eng. 2009, 33, 731-742. [CrossRef]

93. Wang, D.X.; Tong, F.; Aerts, P. Application of the combined ultrafiltration and reverse osmosis for refinery wastewater reuse in Sinopec Yanshan Plant. Desalin. Water Treat. 2011, 25, 133-142. [CrossRef]

94. El-Halwagi, M.M.; Manousiouthakis, V. Synthesis of Mass Exchange Networks. Aich. J. 1989, 35, $1233-1244$. [CrossRef]

95. Wang, Y.P.; Smith, R. Waste-Water Minimization. Chem. Eng. Sci. 1994, 49, 981-1006. [CrossRef]

96. Mann, J.G.; Liu, Y.A. Industrial Water Reuse and Wastewater Mini-Mization, 1st ed.; McGraw-Hill: New York, NY, USA, 1999.

97. Bagajewicz, M. A review of recent design procedures for water networks in refineries and process plants. Comput. Chem. Eng. 2000, 24, 2093-2113. [CrossRef]

98. Koppol, A.R.; Bagajewicz, M.J.; Dericks, B.J.; Savelski, M.J. On zero water discharge solutions in the process industry. Adv. Environ. Res. 2004, 8, 151-171. [CrossRef]

99. Technological regulations of a complex of mechanical treatment facilities for industrial wastewater. "PPCP".

100. Technological regulations of the complex of biological treatment facilities for industrial effluents. "PPCP".

101. Technological regulations of the complex of treatment facilities. "PKOP".

102. Technological regulations of the complex of biological treatment facilities for industrial effluents. "AR".

103. Tussupova, K.; Hjorth, P.; Berndtsson, R. Access to Drinking Water and Sanitation in Rural Kazakhstan. Int. J. Environ. Res. Public Health 2016, 13, 1115. [CrossRef] [PubMed]

104. Tussupova, K.; Berndtsson, R.; Bramryd, T.; Beisenova, R. Investigating Willingness to Pay to Improve Water Supply Services: Application of Contingent Valuation Method. Water 2015, 7, 3024-3039. [CrossRef]

105. Sanitary and Epidemiological Requirements for Water Sources, Water Intake Points for Household and Drinking Purposes, Domestic and Drinking Water Supply and Places of Cultural and Domestic Water Use and Water Safety. Available online: http:/ / adilet.zan.kz/rus/docs/V1500010774 (accessed on 6 March 2019).

106. Pinedo, J.; Ibanez, R.; Lijzen, J.P.A.; Irabien, A. Assessment of soil pollution based on total petroleum hydrocarbons and individual oil substances. J. Environ. Manag. 2013, 130, 72-79. [CrossRef] [PubMed]

107. Peters, C.A.; Knightes, C.D.; Brown, D.G. Long-term composition dynamics of PAH-containing NAPLs and implications for risk assessment. Environ. Sci. Technol. 1999, 33, 4499-4507. [CrossRef]

108. Mcgauhey, P.H. Ground-Water Hydrology-Todd, Dk. Am. J. Public Health 1960, 50, 592. [CrossRef]

109. UNDP. Sustainable Management of Water and Sanitation. Available online: https://www.undp.org/content/ undp/en/home/sustainable-development-goals/goal-6-clean-water-and-sanitation/targets/ (accessed on 6 March 2019).

110. Nanbo, K. Control of Industrial Wastewater in Osaka. Water Pollut. Control Fed. 1980, 52, 992-998.

111. Hamer, G. The impact of government legislation on industrial effluent treatment. Conserv. Recycl. 1985, 8 , 25-43. [CrossRef]

112. EPA. Guide for the Application of Effluent Limitations Guidelines for the Petroleum Refining Industry. 1985. Available online: https:/ / www.epa.gov/sites/production/files/2015-09/documents / petro-refining guidance_june-1985.pdf (accessed on 6 March 2019).

113. Osin, O.A.; Yu, T.Y.; Lin, S.J. Oil refinery wastewater treatment in the Niger Delta, Nigeria: Current practices, challenges, and recommendations. Environ. Sci. Pollut. Res. 2017, 24, 22730-22740. [CrossRef] 
114. Bandyopadhyay, A. Assessment of accidental refinery wastewater discharge: A case study. Clean. Technol. Environ. Policy 2010. [CrossRef]

115. Aljuboury, D.A.A.; Palaniandy, P.; Aziz, H.B.; Feroz, S. Evaluation of the solar photo-Fenton process to treat the petroleum wastewater by response surface methodology (RSM). Environ. Earth Sci. 2016, 75. [CrossRef]

116. Sadatipour, S.M.T.; Mirzaie, L.; Rezaei, A.A. An investigation on Kangan gas refinery wastewater. Int. J. Environ. Sci. Technol. 2004, 1, 205-213. [CrossRef]

117. Haque, N. Exploratory analysis of fines for water pollution in Bangladesh. Water Resour. Ind. 2017, 18, 1-8. [CrossRef]

118. Operating instructions of water supply unit "PPCP".

119. Rebitzer, G.; Ekvall, T.; Frischknecht, R.; Hunkeler, D.; Norris, G.; Rydberg, T.; Schmidt, W.P.; Suh, S.; Weidema, B.P.; Pennington, D.W. Life cycle assessment Part 1: Framework, goal and scope definition, inventory analysis, and applications. Environ. Int. 2004, 30, 701-720. [CrossRef]

120. Katko, T.S.; Hukka, J.J. Social and economic importance of water services in the built environment: Need for more structured thinking. Proc. Econ. Financ. 2015, 21, 217-223. [CrossRef]

(C) 2019 by the authors. Licensee MDPI, Basel, Switzerland. This article is an open access article distributed under the terms and conditions of the Creative Commons Attribution (CC BY) license (http://creativecommons.org/licenses/by/4.0/). 